\title{
Effects of Culture Media on Phytophthora palmivora Growth, $\alpha$-elicitin Production and Toxicity to Dendrobium
}

\section{Apinya KHAIRUM, Oythip POOLSAWAT, Paniti PORNBUNGKERD, Akkawat THARAPREUKSAPONG, Sopone WONGKAEW, Piyada A. TANTASAWAT*}

\author{
Suranaree University of Technology, 111 University Avenue, Muang District, Nakhon Ratchasima 30000, \\ Thailand; apinya_khan@hotmail.com; oythip@gmail.com; paniti_porn@sut.ac.th; \\ akkawat@sut.ac.th;sopone@sut.ac.th;piyada@sut.ac.th (*correspondingauthor)
}

\begin{abstract}
Four culture media were evaluated for their ability to induce Phytophthora palmivora growth and produce culture filtrate (CF), and to determine a CF concentration and culture period effective for in vitro screening of black rot resistance in Dendrobium cv. 'Earsakul'. Mycelial fresh weights of $P$. palmivora cultured in potato dextrose broth (PDB; the most commonly used medium for fungi), pea sucrose broth (PSB; a medium frequently used for Phytophthora spp.), and Murashige and Skoog broth (MSB; the most popular plant tissue culture medium) were found to be significantly higher than that in the newly developed modified oat meal broth (MOMB). When the total proteins of CFs were analysed with SDS-PAGE, a protein band of $10.5 \mathrm{kDa}$ MW was found in CFs from all media with the highest level in PSB. LC-MS/MS analysis identified this protein as $\alpha$-elicitin that had an identical amino acid sequence to the $\alpha$-elicitin hibernalin of $P$. hibernalis and syringicin from $P$. syringae. The optimum conditions for in vitro selection of Dendrobium for black rot resistance using $\alpha$-elicitincontaining CFs were also determined by evaluating the CF toxicity on Dendrobium protocorm-like bodies (PLBs) when cultured in all media supplemented with 0, 30,50 and 100\% CFs for seven, 14 and $21 \mathrm{~d}$. The levels of PLB necrosis varied according to medium types, CF concentrations and culture periods. The maximum percentage of PLB necrosis (100\%) was obtained in PSB supplemented with 50 and 100\% CFs, and the severity of PLB necrosis was highest when treated with 100\% $\mathrm{CF}$ for 14 and $21 \mathrm{~d}$.
\end{abstract}

Keywords: black rot; in vitro; selection; mycelial growth; orchid; pea sucrose broth; toxin

\section{Introduction}

Black rot caused by Phytophthora palmivora is a serious disease of orchids worldwide. The disease is most frequently seen on Cattleya and their hybrids, but it also affects several orchid genera including Dendrobium (Orlikowski and Szkuta, 2006; Cating et al., 2010). Typical symptoms are observed mainly on leaves as black areas in different parts of plants. The optimal temperature for the oomycetal growth is $27.5-30{ }^{\circ} \mathrm{C}$ (Widmer, 2014), therefore it can spread widely in Thailand throughout the year. Several applications of systemic fungicides are often required to protect orchids against black rot; however, they are still limited by cost (McMillan et al., 2009). Therefore, orchid cultivars with black rot resistance are highly desirable.
In the last decade, many toxins produced during plant pathogenesis are known to be phytotoxic (Yoder, 1980). Phytotoxins are low molecular weight substances and secondary metabolites produced by plant pathogenic microorganisms (bacteria, oomycetes and fungi). They are toxic to plants and have been reported to act directly on protoplasts of the cells (Amusa, 2006). CFs of many phytopathogenic microorganisms are known to contain phytotoxic metabolites and toxins have been isolated from them. Moreover, the effects of phytotoxins against host tissues have also been evaluated in vitro in several species (Rao and Ramgoapl, 2010; Dehgahi et al., 2014; Jadon et al., 2015). Meanwhile, purified toxins as well as CFs from different pathogens including Fusarium, Phytophthora and Alternaria etc. were used for in vitro selection to obtain new resistant lines (Savita et al., 2011; Esmaiel et al., 2012; Lecomte et al., 2014). Phytophthora spp. have been reported 
to secrete a variety of proteins including elicitins, $P$. cactorum-Fragaria protein $(\mathrm{PcF})$, crinkling- and necrosisinducing protein $(\mathrm{CRN})$, cellulose-binding elicitor and lectin-like proteins, and necrosis- and ethylene-inducinglike protein (NLP) (Dong et al., 2012). Elicitins are $10 \mathrm{kDa}$ extracellular proteins with 98 amino acids which can be divided into diverse classes including elicitins (class $\mathrm{I} \alpha$ [acidic elicitins], I $\beta$ [basic elicitins] and II [highly acidic elicitin]) and elicitin-like proteins. They were found in $P$. infestans, $P$. sojae, $P$. brassicae and $P$. ramorum (Jiang et al., 2006). Plants recognize elicitin conserved structure known as microbe- or pathogen-associated molecular patterns (MAMPs or PAMPs) by pattern recognition receptors (PRRs) (Zipfel and Robatzek, 2010; Derevnina et al., 2016; Uhlíková et al., 2016). Sensing of MAMPs or PAMPs lead to MAMP- or PAMP-triggered immunity (MTI or PTI) that can overcome microbe or pathogen infection by inducing primary defense responses and thus increase plant resistance to pathogens (Zipfel and Robatzek, 2010; Oßwald et al., 2014; Saubeau et al., 2014) Moreover, receptor-like protein ELR (elicitin response) is one of the first cell surface receptors known to mediate hypersensitive response (HR) (Du et al., 2015). Its biological activities involve induction of $\mathrm{HR}$, systemic acquired resistance (SAR), phytoalexin, and pathogenesis related (PR) proteins as well as activation of necrotic response and electrolyte leakage (Capasso et al., 2001; Baillieul et al., 2003). It has been shown that $\alpha$-elicitin of $P$. plurivora has dual roles in a susceptible interaction; association with the penetration of the pathogen by unknown mechanisms and suppression of important defense genes of host plants. The functions of $\alpha$ elicitins may also be related to later stages of infection, especially sporulation and/or pathogen survival under saprophytic conditions. Therefore, elicitins appear to have conflicting functions, promoting virulence as well as serving as avirulent determinants by eliciting defense responses. Qualitative and quantitative differences in HR cell death induction and SAR indicated that the genetic basis of response to elicitin depend on variable plant taxa and types of elicitin. Thus, elicitins induce HR in some plant species including tobacco, potato, pepper, grapevine, citrus etc., whereas they exhibit lack of responsive capacity in other species e.g., tomato (Kamoun et al., 1993; Oßwald et al., 2014; Derevnina et al., 2016). However, the response of Dendrobium has not been studied.

In vitro selection using pathogenic toxins offers an effective means of screening for disease resistance in crop improvement programs because it allows greater environmental control, requires a smaller space, and is faster than conventional breeding (Rao and Ramgoapl, 2010; Savita et al., 2011). However, to effectively differentiate resistant and susceptible plants, a good selection system needs to be developed.

The objectives of this study were to evaluate the production of toxin-containing CF of $P$. palmivora on different oomycetal culture media and to determine an effective concentration of CF and the culture period to be used for screening black rot resistance in Dendrobium cv. 'Earsakul'. In addition, we identified the major protein secreted into CF as $\alpha$-elicitin by using LC-MS/MS analysis.

\section{Materials and Methods} filtrates

Phytophthora palmivora culture and preparation of culture

Single-conidial cultures of $P$. palmivora isolate NK-53-9 (the most virulent isolate; Khairum et al., 2016) were maintained in potato dextrose agar (PDA; 20\% (w/v) potato, $2 \%(\mathrm{w} / \mathrm{v})$ dextrose and $2 \%(\mathrm{w} / \mathrm{v})$ agar) under UV blacklight at $18-25^{\circ} \mathrm{C}$ for $5 \mathrm{~d}$. Two pieces $(\Phi=1 \mathrm{~cm})$ of a PDA with fungal mycelium were transferred to each flask containing $100 \mathrm{~mL}$ of four oomycetal culture media: potato dextrose broth $[\mathrm{PDB} ; 20 \%(\mathrm{w} / \mathrm{v})$ potato and $2 \%(\mathrm{w} / \mathrm{v})$ dextrose; the most commonly used medium for fungi], pea sucrose broth [PSB; $12.5 \%(\mathrm{w} / \mathrm{v})$ pea and $1 \%(\mathrm{w} / \mathrm{v})$ sucrose; a medium frequently used for Phytophthora spp.], modified oat meal broth $[\mathrm{MOMB} ; 5 \%(\mathrm{w} / \mathrm{v})$ oat, $5 \%(\mathrm{w} / \mathrm{v})$ rice bran, $5 \%(\mathrm{w} / \mathrm{v})$ potato and $1 \%(\mathrm{w} / \mathrm{v})$ sucrose; the newly developed medium for spore induction in our laboratory], and Murashige and Skoog broth [MSB; MS salts (Murashige and Skoog, 1962) and 2\% (w/v) sucrose; the most popular plant tissue culture medium], and incubated with shaking at $100 \mathrm{rpm}$ in the dark at $24-25^{\circ} \mathrm{C}$ for $20 \mathrm{~d}$. After incubation, the cultures were filtered through Whatman No.1 filter paper and the $\mathrm{pH}$ of the resulting CF was adjusted to $5.6 \pm 0.2$. The CF thus collected was filtersterilized using $0.2 \mu \mathrm{m}$ membrane filter discs and stored at $20^{\circ} \mathrm{C}$ until required. The mycelium remaining on the filter paper was weighed to estimate oomycetal growth in each medium.

\section{Sodium dodecyl sulfate-polyacrylamide gel electrophoresis} (SDS-PAGE)

The CFs of $P$. palmivora were harvested from four oomycetal culture media (PDB, PSB, MOMB and MSB $\mathrm{CFs}$ ) after $20 \mathrm{~d}$. Controls were $P$. palmivora-free oomycetal culture media (PDB, PSB, MOMB and MSB). Protein electrophoresis was carried out under denaturing conditions according to the modified method of Laemmli (1970) by SDS-PAGE with 16\% separating gel and 4\% stacking gel. The samples were boiled for $5 \mathrm{~min}$ at $95^{\circ} \mathrm{C}$ with a reducing sample buffer (containing 2-mercaptoethanol) and $3 \mu \mathrm{L}$ of each sample were loaded in the gel. Electrophoresis was performed at $180 \mathrm{~V}$ for $90 \mathrm{~min}$. Staining was performed by using $0.1 \%$ silver nitrate (Rockefeller University, 2016). The experiment was repeated four times with consistent results. A gel was stained by colloidal coomassie blue G250.

\section{In-gel digestion and LC-MS/MS analysis}

The protein band of interest was excised from the gel, and the band was cut into $2 \mathrm{~mm}^{2}$ pieces and placed into a $1.5 \mathrm{~mL}$ microcentrifuge tube. For in-gel digestion, trypsin (Promega, WI, USA) solution was added and digested at $4{ }^{\circ} \mathrm{C}$ for 30 min. Gel pieces were incubated with $25 \mathrm{mM}$ Ambic overnight at $37^{\circ} \mathrm{C}$. Peptides were extracted with 50\% ACN and $1 \%$ formic acid, and dried with a centriVap centrifugal vacuum concentrator for $2 \mathrm{~h}$, followed by reconstruction with buffer ( $2 \% \mathrm{ACN}$ and $0.1 \%$ formic acid). Peptide identification was analyzed by liquid chromatography-mass spectrometer/ mass spectrometer (LC-MS/MS) analysis (Sharma et al., 2014; Rodpai et al., 2016). 
632

Protein identification was performed by searching against the protein database from NCBIprot (Other Eukaryote) using MASCOT MS/MS Ion Search (http://www.matrixscience.com) with the initial searching parameters of Enzyme and Trypsin, which allowed up to three missed cleavages; carbamidomethylation as fixed modification, and oxidation (HW) and oxidation (M) as variable modifications; peptide mass tolerance of $0.5 \mathrm{Da}$ and fragment mass tolerance of $0.6 \mathrm{Da}$; a peptide charge state of $+1,+2,+3$; instrument type (ESI-QUAD-TOF); and report top (Auto). The obtained peptide sequence from $P$. palmivora CFs was compared with the NCBI database which was restricted to the taxonomy of elicitin in Phytophthora species. Sequence identification of proteins was performed against known protein sequences in the NCBI database using the protein-protein basic local alignment search tool (BLASTp) (https://blast.ncbi.nlm.nih.gov/Blast.cgi?PAGE=Proteins). These protein sequences were aligned by using the MEGA 7.0 program.

\section{Assessment of culture filtrates for in vitro selection}

PLBs (50 PLBs per treatment) of Dendrobium cv. 'Earsakul' were cultured together with CFs at final concentrations of $0,30,50$ and $100 \%(\mathrm{v} / \mathrm{v})$ in four oomycetal culture media (PDB, PSB, MOMB and MSB) and incubated with shaking at $50 \mathrm{rpm}$ for seven, 14 and 21 $\mathrm{d}$ at $25^{\circ} \mathrm{C}$ and a $12 \mathrm{~h}$ photoperiod.

\section{Toxicity analysis}

The toxic effects of the CFs were determined by the appearance of necrosis on PLBs. Two parameters were evaluated at seven, 14 and $21 \mathrm{~d}$; the percentages of necrotic PLBs [(number of PLBs with a necrosis symptom/ total PLBs) $\times 100$ ], and severity of necrosis (a $0-5$ scale based on necrotic area per PLB (\%); $0=0 \%, 1=1-20 \%, 2=21-40 \%$, $3=41-60 \%, 4=61-80 \%$ and $5=81-100 \%$ ).

\section{Statistical analysis}

A completely randomized design with five replications (one flask of ten PLBs per replication) was used. Data was analyzed using analysis of variance (ANOVA) of mycelial fresh weight, arcsine transformed percentage of necrotic PLBs and $(X+1)^{1 / 2}$ transformed severity of necrosis score. A mean comparison was performed by Duncan's multiple range test (DMRT) to evaluate the differences in ability to promote mycelial growth and toxin production of various CFs using the SPSS version 14.0 (Levesque and SPSS Inc., 2006).

\section{Results and Discussion}

Effects of oomycetal culture media on mycelium growth of Phytophthora palmivora

After culturing isolate NK-53-9 of $P$. palmivora which exhibited the highest virulence in Dendrobium detached leaf assay (Khairum et al., 2016) for $20 \mathrm{~d}$ in four different oomycetal culture media (PDB, PSB, MOMB and MSB), it was found that the fresh weights of mycelium cultured in four different oomycetal culture media were significantly different $(p<0.05)$. The highest mycelial fresh weight was observed in the PSB medium (4.89 g), but it was not significantly different from those cultured in PDB and MSB $(4.29 \mathrm{~g})$. However, mycelial growth was significantly lower in MOMB (1.6-fold; Table 1). The pea medium with added sucrose has also been reported to promote a high rate of mycelial growth of $P$. cinnamomi (Chee and Newhook, 1965a, 1965b). The Phytophthora species usually grow best on natural or synthetic media containing thiamine, a suitable carbon source such as sucrose, nitrogen sources, inorganic salts and minor elements (Erwin and Ribeiro, 1996). Sterols are not essential for vegetative growth, nevertheless, in a sterol-containing medium Phytophthora takes it up and enhances growth (dry weight or colony diameter) (Hendrix, 1964; Elliott, 1994). The main sterol constituents from pea seeds and oat grains were identified as sitosterol by chromatography (Ryan et al., 2007; Gangopadhyay et al., 2015). This sterol has proven its ability to enhance mycelial growth and could promote the most rapid growth of $P$. infestants (Dahlin et al., 2017).

Previous reports have also shown that oat meal agar (OMA) was optimal for mycelial growth of $P$. palmivora (Awuah and Frimpong, 2002), P. infestans (Sopee et al., 2012) and P. megasperma var. sojae (Ho, 1970). However, the MOMB medium appeared to promote the least growth of $P$. palmivora in our system (Table 1). Because of the high cost of oats, this medium was modified by supplementing with potato and rice bran. Natural media containing potato tuber, which contains suitable sources of nitrogen, mineral salts and growth factors, and sugar was found to be appropriate for the growth of most fungi (Beever and Bollard, 1970; Sumbali, 2010). Meanwhile rice bran, a byproduct of rice milling, is the best source of phytosterols, especially $B$-sitosterol (the major sterol in rice bran) (Derakhshan-Honaroarvar et al., 2010; Özdestan et al., 2014). However, several researchers reported that rice bran contains bioactive compounds (e.g., phenolics, proteins) that could inhibit fungal growth, biomass and mycotoxigenic potential in some pathogenic fungi such as Rhyzopus oryzae (Souza et al., 2010), Colletotrichum gloeosporioides (Phungamngoen and Sungsri-in, 2011) and Fusarium graminearum (Fernanda et al., 2013). The presence of these bioactive compounds may negatively affect growth of $P$.palmivora in MOMB.

Identification of secreted protein in culture filtrates of Phytophthora palmivora and effects of culture media on its production

In the present investigation, $P$. palmivora was found to secrete a protein into the oomycetal culture media. When the total proteins from the obtained CFs were separated based on molecular weight using SDS-PAGE, the silver staining clearly revealed a major protein band with ca. 10.5 $\mathrm{kDa}$ MW. This protein was not found in P. palmivora-free control, but was present in all $P$. palmivora CFs at different quantities PSB > PDB > MOMB > MSB (Fig. 1). The MW of this protein is comparable to elicitins that were previously reported in sexual Phytopthora spp. (Churngchow and Rattarasarn, 2000). In CF of $P$. palmivora, the causal agent of rubber, palmivorein, a small secreted protein of ca. $10 \mathrm{kDa} \mathrm{MW}$ in the elicitin family, 
Table 1. Similarity search between $\alpha$-elicitin hibernalin protein sequence and accessions in NCBI database using BLASTp

\begin{tabular}{|c|c|c|}
\hline Proteins & E-value ${ }^{a}$ & $\begin{array}{c}\text { Identity/ } \\
\text { Query cover (\%) }\end{array}$ \\
\hline$\alpha$-elicitin syringicin $[\text { P. syringae; } \mathrm{P} 85436.1]^{\mathrm{b}}$ & $7 e-62$ & $100 / 100$ \\
\hline$\alpha$-elicitin INF1 [P. capsici; AFY98083.1] & $7 e-60$ & $97 / 100$ \\
\hline Sojein 1 protein [P. sojae; CAA07710.1] & $3 e-59$ & $96 / 100$ \\
\hline Sojein 4 protein [P. sojae; CAA07713.1] & $4 e-58$ & $95 / 100$ \\
\hline$\alpha$-elicitin, infestin [P. infestans, peptide 98 aa; AAB31120.1] & $5 e-58$ & $93 / 100$ \\
\hline Sojein 3 protein [P. sojae; CAA07712.1] & $2 e-57$ & $93 / 100$ \\
\hline$\alpha$-elicitin MGM- $\alpha$ [P. megasperma; P35689.1] & $3 e-57$ & $93 / 100$ \\
\hline Sojein 2 protein [P. sojae; CAA07711.1] & $3 e-56$ & $92 / 100$ \\
\hline$\alpha$-elicitin DRE- $\alpha[$ P. drechsleri; P35696.1] & $1 e-54$ & $89 / 100$ \\
\hline B-elicitin DRE- $ß[$ P. drechsleri; P35697.1] & $1 e-52$ & $86 / 100$ \\
\hline Chain A, structure of fungal elicitor, nmr, 18 structures [P. cryptogea; 1BEG_A] & $3 e-51$ & $84 / 100$ \\
\hline B-elicitin cryptogein; Short=CRY [P. cryptogea; P15570.2] & $4 e-51$ & $84 / 100$ \\
\hline Chain A, B-cryptogein-chloresterol complex [P.cryptogea; 1LRI_A] & $8 \mathrm{e}-51$ & $83 / 100$ \\
\hline Elicitin [P.sojae; XP_009532175.1] & $2 \mathrm{e}-50$ & $82 / 100$ \\
\hline ß-megaspermin [P. megasperma; CAD38502.1] & $2 \mathrm{e}-50$ & $83 / 100$ \\
\hline B-elicitin cinnamomin $[$ P. cinnamomi; $\mathrm{P} 15569.1]$ & $3 e-50$ & $83 / 100$ \\
\hline Highly acidic elicitin [Phytophthora $\times$ multiformis; AAY85663.1] & $6 e-50$ & $82 / 100$ \\
\hline Cinnamomin $[$ P. cinnamomi; CAB38321.1] & $6 e-50$ & $83 / 100$ \\
\hline Highly acidic elicitin [P. cinnamomi; CAB38324.1] & $1 e-49$ & $83 / 100$ \\
\hline Hypothetical protein PHYSODRAFT_355153 [P.sojae; XP_009532176.1] & $8 \mathrm{e}-49$ & $81 / 100$ \\
\hline Basic elicitin partial [P. uniformis; ABM53007.1] & $2 \mathrm{e}-48$ & $80 / 100$ \\
\hline Basic elicitin partial [Phytophthora $\times$ alni; ABM52996.1] & $2 \mathrm{e}-48$ & $80 / 100$ \\
\hline Basic elicitin partial [Phytophthora $\times$ multiformis; ABM53003.1] & $2 \mathrm{e}-48$ & $80 / 100$ \\
\hline$\alpha$-elicitin 2 [P. lateralis; ABG75610.1] & $2 \mathrm{e}-48$ & $80 / 100$ \\
\hline Basic elicitin [Phytophthora $\times$ multiformis; AAY85665.1] & $3 e-48$ & $80 / 100$ \\
\hline Basic elicitin [Phytophthora $\times$ alni; AAY85677.1] & $1 e-47$ & $79 / 100$ \\
\hline Acidic elicitin [P.palmivora; AJE68929.1] & $6 e-51$ & $93 / 88$ \\
\hline
\end{tabular}

${ }^{a}$ Expected value ( $E$-value) refer to the number of matches expected by chance alone. The lower the $E$-value, the more strongly supported the match.

${ }^{b} \mathrm{NCBI}$ accession number.

was isolated and has been shown to cause necrosis on tobacco and rubber leaves (Churngchow and Rattarasarn, 2000). It is interesting to note that appreciable differences in an extracellular $10.5 \mathrm{kDa}$ protein quantities were observed among CFs that were harvested from four oomycetal culture media, suggesting the differential effects of various media on $P$. palmivora protein production and/or secretion.

When the secreted protein was identified by LCMS/MS, it showed the presence of LMCASTACK peptide, which was found to significantly match $\alpha$-elicitin hibernalin and syringicin proteins from $P$. hibernalis, the causal pathogen of citrus lemon brown rot and $P$. syringae, the causal pathogen of citrus fruit rot, respectively. Its MW was estimated by LC-MS/MS as ca. $10.536 \mathrm{kDa}$ with $4.68 \mathrm{pI}$, which is very close to the three $\alpha$-elicitins, named hibernalin1, hibernalin 2 and hibernalin 3 (hib1, hib2 and hib3 with MW of $10.19,10.21$ and $10.22 \mathrm{kDa}$, respectively) found in P. hibernalis Carne $1925 \mathrm{CF}$, and close to the $10.19 \mathrm{kDa}$ MW of syringicin (Capasso et al., 2001; Capasso et al., 2008). Hibl was shown to be active in both the hypersensitivity response and electrolyte leakage assays. Furthermore, it was found to induce defense responses in resistant potato plants against $P$. infestans, for example, increasing expression of glucose oxidase, NADPH oxidase, superoxide dismutase, glutathione reductase, catalase and peroxidase enzymes (Saubeau et al., 2014). These results suggest that these elicitins may play an important role in host-pathogen interactions.

When one hundred protein sequences from 22 Phytophthora spp. from the NCBI database were compared, it was shown that 28 of these protein sequences shared high homology to $\alpha$-elicitin hibernalin and syringicin (supported by $E$-value close to 0 ) including acidic elicitin from $P$. palmivora infecting rubber (Table 1). Although these elicitins were isolated from different Phytophthora species infecting different host plants (Capasso et al., 2008). These results suggest that particular elicitin member(s) may be conservative in diverse Phytophthora species, possibly possessing crucial functions in pathogenesis. Phylogenetic analysis based on the mature protein sequences of the 28 elicitins from 22 Phythophthora spp. separated them into three major clusters, cluster I, II and III. Fourteen were grouped into cluster I. This cluster was divided into two subclusters (IA and IB). Subcluster IA consisted of five $\beta$ elicitins and one hypothetical protein from five Phythophthora spp. infecting several plants (Phytophthora $\times$ multiformis, Phytophthora $\times$ alni, P. uniformis, P. sojae and P. cinnamomi). Subcluster IB consisted of two $\alpha$-elicitins 
634

and $\beta$-elicitins from three other Phythophthora spp. ( $P$. drechsleri, $P$. megasperma and $P$. cryptogea). Cluster II consisted of nine $\alpha$-elicitin $(\alpha$-elicitin hibernalin, $\alpha$-elicitin syringicin, $\alpha$-elicitin INF1, $\alpha$-elicitin MGM- $\alpha$, acidic elicitin

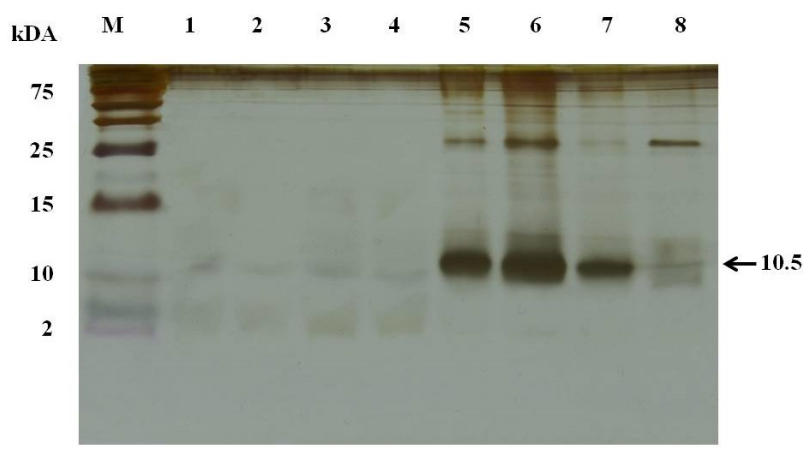

Fig. 1. SDS-PAGE of extracellular proteins secreted by $P$. palmivora after being cultured for $21 \mathrm{~d}$. Standard proteins (M), four controls ( $P$. palmivora-free oomycetal culture media; $\mathrm{PDB}, \mathrm{PSB}, \mathrm{MOMB}$ and MSB; lanes one to four, respectively) and $P$. palmivora $\mathrm{CFs}$ on four different oomycetal culture media (PDB, PSB, MOMB and MSB; lanes five to eight, respectively). sojein 1 protein, sojein 4 protein, sojein 3 protein and sojein 2 protein) from $P$. hibernalis, $P$. syringae, $P$. capsici, $P$. palmivora, $P$. megasperma and $P$. sojae in subcluster IIA and one separated individual from $P$. infestans ( $\alpha$-elicitin, infestin). By contrast, cluster III consisted of four $\alpha$-elicitins from $P$. sojae, Phytophthora $\times$ multiformis, $P$. cinnamomi and $P$. lateralis (Fig. 2). These results suggest that there is no relationship between these elicitin amino acid sequences based on either pathogen species or host plants.

Effects of oomycetal culture media on toxicity of culture filtrate and determination of optimum conditions for in vitro selection of Dendrobium protocorm-like bodies (PLBs)

In order to obtain a suitable oomycetal culture medium for the production of $P$. palmivora $\mathrm{CF}$ with maximum efficiency for in vitro selection of black rot resistance in Dendrobium, four different oomycetal culture media (PDB, $\mathrm{PSB}, \mathrm{MOMB}$ and MSB), four different concentrations of CF [0 (control), 30, 50 and 100\%] and three culture periods (seven, 14 and $21 \mathrm{~d}$ ) were evaluated. In vitro selection of Dendrobium PLBs in $\alpha$-elicitin-containing CFs showed that the effects of medium types were highly significant $(\mathrm{p}<$ 0.01 ) on percentages of necrotic PLBs and severity of
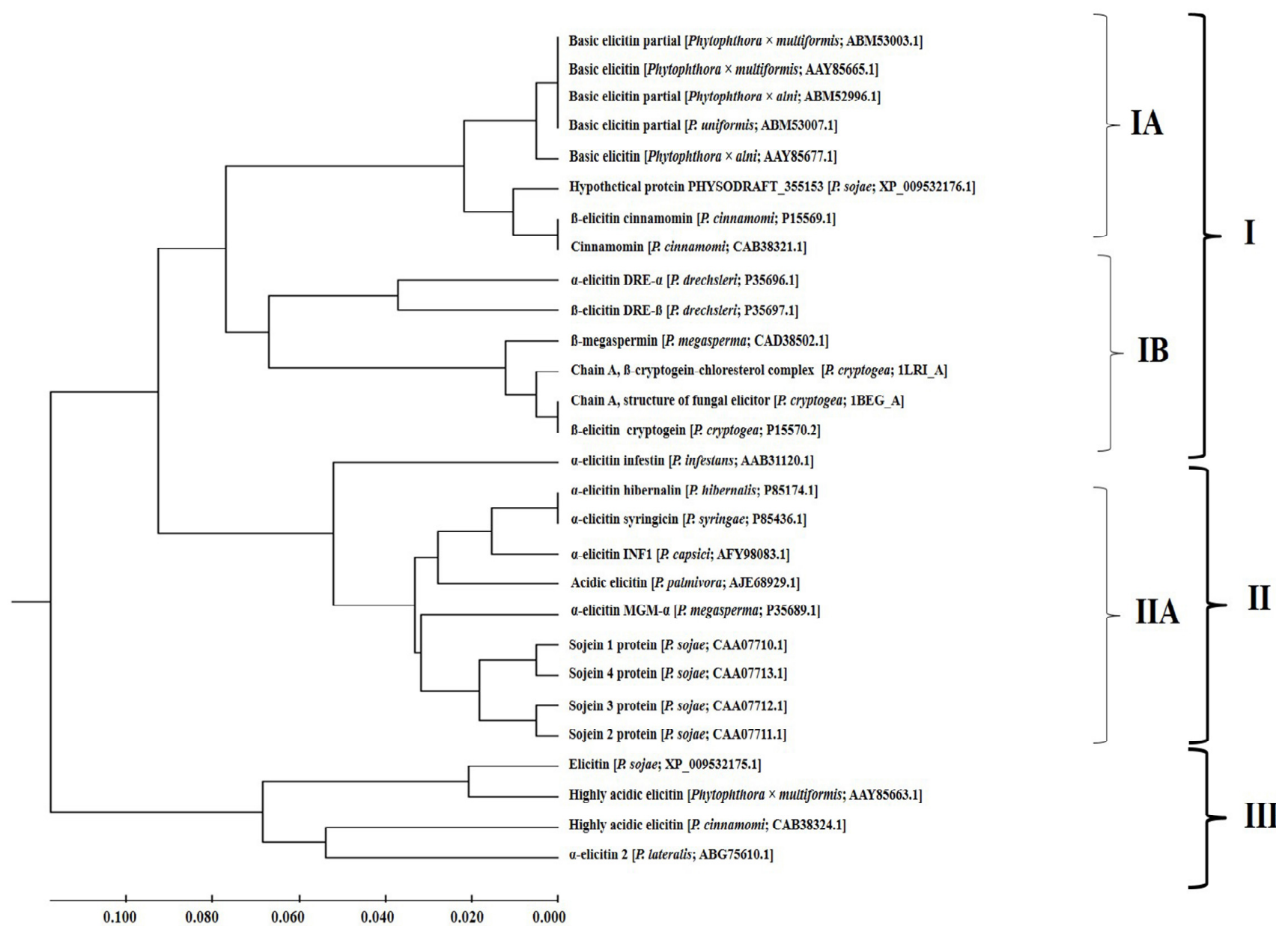

Fig. 2. Phylogenetic analysis of $\alpha$-elicitins from different Phytophthora spp. with $\alpha$-elicitin hibernalin (P. hibernalis) based on the mature protein sequences. 
necrosis. The highest toxicity was obtained in the PSB medium with an average percentage of necrotic PLBs of $65.09 \%$ and an average severity of necrosis score of 1.31 , which were significantly higher than those of other media, particularly MSB (Table 2). Different concentrations of CFs also affected percentages of necrotic PLBs and severity of necrosis significantly $(\mathrm{p}<0.01)$. PLB necrosis increased as CF concentrations increased. The most effective CF concentration for in vitro selection was $100 \%$ with an average percentage of necrotic PLBs of $76.14 \%$ and an average severity of necrosis score of 1.43 . Nevertheless, the reduction of CF concentration from 100 to $50 \%$ decreased the percentage of necrotic PLBs by only $13 \%$ (Table 3 ). Among the three culture periods used in this study, there were no significant differences $(p>0.05)$ on percentages of necrotic PLBs. However, a highly significant difference $(\mathrm{p}<$ 0.01 ) was observed among the culture periods on severity of necrosis. It was shown that necrosis increased as the culture period increased, and the highest average severity of necrosis score (0.99) was reached at $21 \mathrm{~d}$ (Table 4). When all three

Table 2. Effects of four different oomycetal culture media on fresh weight of Phytophthora palmivora mycelium at $20 \mathrm{~d}$ after culture

\begin{tabular}{cr}
\hline Oomycetal culture media & Fresh weight of mycelium (g) \\
\hline PDB & $4.29 \pm 0.38 \mathrm{a}^{\mathrm{a}}$ \\
PSB & $4.89 \pm 0.20 \mathrm{a}$ \\
MOMB & $3.11 \pm 0.55 \mathrm{~b}$ \\
MSB & $4.29 \pm 0.10 \mathrm{a}$
\end{tabular}

${ }^{\mathrm{a}}$ Data are presented as means \pm SE. Means in the same column with different letters are significantly different (Duncan's multiple range test (DMRT), $\left.\mathrm{p}<0.05\right)$.

Table 3. Effects of four different oomycetal culture media of Phytophthora palmivora on percentages of necrotic protocorm-like bodies (PLBs) and necrosis severity of Dendrobium cv. 'Earsakul'

\begin{tabular}{ccc}
\hline Oomycetal culture media & Necrotic PLBs (\%) & Severity of necrosis $^{\mathrm{b}}$ \\
\hline PDB & $56.11 \pm 6.00 \mathrm{~b}^{\mathrm{a}}$ & $0.77 \pm 0.04 \mathrm{~b}$ \\
PSB & $65.09 \pm 6.11 \mathrm{a}$ & $1.31 \pm 0.06 \mathrm{a}$ \\
MOMB & $55.96 \pm 5.48 \mathrm{~b}$ & $0.74 \pm 0.04 \mathrm{~b}$ \\
MSB & $8.43 \pm 3.02 \mathrm{c}$ & $0.09 \pm 0.01 \mathrm{c}$ \\
\hline${ }^{\mathrm{a}}$ Data are presented as means \pm SE. Means in the same column with different letters are significantly different (Duncan's multiple range test (DMRT), $\left.\mathrm{p}<0.05\right)$. &
\end{tabular}

Table 4. Effects of four different concentrations of culture filtrates of Phytophthora palmivora on percentages of necrotic protocorm-like bodies (PLBs) and necrosis severity of Dendrobium cv. 'Earsakul'

\begin{tabular}{ccc}
\hline Concentrations of culture filtrate $(\%)$ & Necrotic PLBs $(\%)$ & Severity of necrosis \\
\hline 0 (Control) & $0.00 \pm 0.00 \mathrm{~d}^{\mathrm{a}}$ & $0.00 \pm 0.00 \mathrm{~d}$ \\
30 & $46.20 \pm 5.72 \mathrm{c}$ & $0.61 \pm 0.04 \mathrm{c}$ \\
50 & $66.25 \pm 5.63 \mathrm{~b}$ & $0.93 \pm 0.03 \mathrm{~b}$ \\
100 & $76.14 \pm 4.86 \mathrm{a}$ & $1.43 \pm 0.05 \mathrm{a}$ \\
${ }^{\mathrm{a}}$ Data are presented as means \pm SE. Means in the same column with different letters are significantly different (Duncan's multiple range test (DMRT), $\left.\mathrm{p}<0.05\right)$.
\end{tabular}

${ }^{\mathrm{a}}$ Data are presented as means \pm SE. Means in the same column with different letters are significantly different (Duncan's multiple range test (DMRT
${ }^{\mathrm{b}}$ Severity of necrosis score $(0-5$ scale based on necrotic area per PLB $(\%) ; 0=0 \%, 1=1-20 \%, 2=21-40 \%, 3=41-60 \%, 4=61-80 \%$ and $5=81-100 \%)$.

Table 5. Effects of three culture periods on percentages of necrotic protocorm-like bodies (PLBs) and necrosis severity of Dendrobium cv. 'Earsakul'

\begin{tabular}{ccc}
\hline Culture periods $(\mathrm{d})$ & Necrotic PLBs $(\%)^{\text {Severity of necrosis }}{ }^{\mathrm{b}}$ & $0.50 \pm 0.02 \mathrm{c}$ \\
7 & $42.89 \pm 5.14^{\mathrm{a}}$ & $0.77 \pm 0.04 \mathrm{~b}$ \\
14 & $48.06 \pm 5.34$ & $0.99 \pm 0.05 \mathrm{a}$ \\
\hline 21 & $51.27 \pm 5.53$ &
\end{tabular}

${ }^{a}$ Data are presented as means \pm SE. Means in the same column with different letters are significantly different (Duncan's multiple range test (DMRT), $\left.\mathrm{p}<0.05\right)$.

${ }^{\mathrm{b}}$ Severity of necrosis score $(0-5$ scale based on necrotic area per PLB $(\%) ; 0=0 \%, 1=1-20 \%, 2=21-40 \%, 3=41-60 \%, 4=61-80 \%$ and $5=81-100 \%)$.

Table 6. Percentages of necrotic protocorm-like bodies (PLBs) and necrosis severity of Dendrobium cv. 'Earsakul' cultured in PSB medium supplemented with various culture filtrate concentrations at different culture periods

\begin{tabular}{|c|c|c|c|}
\hline Culture filtrate concentrations (\%) & Culture periods (d) & Necrotic PLBs (\%) & Severity of necrosis ${ }^{b}$ \\
\hline \multirow{3}{*}{$\begin{array}{c}0 \\
\text { (control) }\end{array}$} & 7 & $0.00 \pm 0.00 c^{a}$ & $0.00 \pm 0.00 \mathrm{~g}$ \\
\hline & 14 & $0.00 \pm 0.00 \mathrm{c}$ & $0.00 \pm 0.00 \mathrm{~g}$ \\
\hline & 21 & $0.00 \pm 0.00 \mathrm{c}$ & $0.00 \pm 0.00 \mathrm{~g}$ \\
\hline \multirow{3}{*}{30} & 7 & $64.00 \pm 20.15 b$ & $0.64 \pm 0.07 \mathrm{f}$ \\
\hline & 14 & $68.00 \pm 19.60 \mathrm{ab}$ & $1.08 \pm 0.16 \mathrm{e}$ \\
\hline & 21 & $70.00 \pm 18.44 \mathrm{ab}$ & $1.26 \pm 0.17 \mathrm{e}$ \\
\hline \multirow{3}{*}{50} & 7 & $100.00 \pm 0.00 \mathrm{a}$ & $1.08 \pm 0.04 \mathrm{e}$ \\
\hline & 14 & $100.00 \pm 0.00 \mathrm{a}$ & $1.45 \pm 0.09 \mathrm{~d}$ \\
\hline & 21 & $100.00 \pm 0.00 \mathrm{a}$ & $2.08 \pm 0.08 b$ \\
\hline \multirow{3}{*}{100} & 7 & $100.00 \pm 0.00 \mathrm{a}$ & $1.78 \pm 0.13 \mathrm{c}$ \\
\hline & 14 & $100.00 \pm 0.00 \mathrm{a}$ & $3.10 \pm 0.10 \mathrm{a}$ \\
\hline & 21 & $100.00 \pm 0.00 \mathrm{a}$ & $3.40 \pm 0.11 \mathrm{a}$ \\
\hline
\end{tabular}

${ }^{\bar{a}}$ Data are presented as means \pm SE. Means in the same column with different letters are significantly different (Duncan's multiple range test (DMRT), $\left.\mathrm{p}<0.05\right)$.

${ }^{\mathrm{b}}$ Severity of necrosis score $(0-5$ scale based on necrotic area per PLB $(\%) ; 0=0 \%, 1=1-20 \%, 2=21-40 \%, 3=41-60 \%, 4=61-80 \%$ and $5=81-100 \%)$. 
636

factors were considered, the maximum percentage of necrotic PLB (100\%) was obtained in the PSB medium supplemented with 50 and $100 \%$ CFs for seven, 14 and 21 d. Severity of necrosis on PLBs was the highest when treated with $100 \%$ CF in PSB medium for 14 and $21 \mathrm{~d}$, however, the necrotic symptoms became evident at a lower concentration (50\% CF) after $21 \mathrm{~d}$ (Table 5). PLBs selected in PSB medium at $21 \mathrm{~d}$ also appeared more necrotic (brown and black) than PLBs selected in other oomycetal culture media at the same concentrations of CFs. By contrast, control PLBs ( $0 \% \mathrm{CF})$ remained green in all culture media throughout the experiment (data not shown).

Our results reveal that the PSB CF at a concentration of $50 \%$ selected for $21 \mathrm{~d}$ is the most suitable condition for efficient in vitro selection for black rot resistance in Dendrobium since it requires the lowest CF concentration that allows $100 \%$ of necrotic PLBs (Table 6). Under this condition, most of the necrotic PLBs died after being transferred to a CF-free medium, allowing selection of the mutant PLBs that are toxicity resistant which can survive and develop into plantlets.

Using this condition for in vitro selection of Dendrobium cv. 'Earsakul' PLBs, we were able to obtain several putative mutants that were resistant to $P$. palmivora in the detached leaf assay (Khairum et al., 2016; Khairum $e t$ al., unpublished data). Similarly, the PSB medium was successfully used to obtain CF of $P$. parasitica for in vitro selection of Citrus jambhiri for resistance to root and crown rot as well as foot rot and brown rot of fruits (Savita et al., 2011). However, in P. capsici, CFB was optimal for toxin production (Qi et al., 2006). Our results on the optimal culture period ( $21 \mathrm{~d}$ ) are in good agreement with a report from Behnke (1979) which showed that most of the potato calli became brownish and stopped growing in toxic media after three weeks. The phytotoxicity effects of toxins and CFs as well as their usefulness for in vitro selection have also been demonstrated in other plant-pathogen systems (Savita et al., 2011; Dehgahi et al., 2014; Valencia et al., 2014). However, as far as we know, we are the first to report the usage of $P$. palmivora CF for in vitro selection in Dendrobium.

It is interesting to note that the PSB medium is also suitable for mycelial growth of $P$. palmivora resulting in the highest fresh weight of mycelium (Table 2). MSB and PDB were able to induce comparable mycelial growth with PSB, but they produced lower toxin levels than PSB, as suggested by significantly lower percentages of necrotic PLBs and severity of necrosis (Tables 2 and 3 ). Necrosis and plant cell death were correlated with genetic basis of response to toxic metabolites or secreted proteins including elicitin from Phytophthora spp., which was variable depending on plant taxa. It is possible that the $\alpha$-elicitin caused tissue necrosis of Dendrobium PLBs since its levels in CFs appear to correlate well with the extent of necrotic responses, however, this needs to be elucidated by future experiment with purified $\alpha$ elicitin. Oomycete growth and sporulation in vitro is influenced by sterol contents and is highly correlated with sterol binding, especially in Phytophthora and Pythium spp. (Osman et al., 2001; Stong et al., 2013). Elicitin can act as sterol carriers by scavenging sterols from plasma membranes of host cells. Upon sterol binding, elicitin was initially suggested to disrupt plasma membrane integrity, leading to induced cell death (Derevnina et al., 2016). And it has also been reported that only a sterol-elicitin complex binds to a plasmalemma receptor and triggers the biological responses of plants (Ponchet et al., 1999; Osman et al., 2001). Although recent findings suggested that sterol binding may be independent from defense elicitation (Dokladal et al., 2012; Derevnina et al., 2016; Uhliková et al., 2016), its involvement may vary with plant species. Natural additives (legumes, vegetables and cereals) in oomycetal culture media are the main sources of plant sterols/ phytosterols, which are known to be structural components of plant cell membrane (Moreau et al., 2002; Lagarda et al., 2006). High total plant sterols (1,337 $\mathrm{mg} \mathrm{kg}^{-1}$ dry weight) were measured in pea and lower contents (246 mg kg-1 dry weight) were found in potato (Piironen et al., 2003). In whole grain oats, the total sterol contents were $350-491 \mathrm{mg} \mathrm{kg}^{-1}$ dry weight of kernel (Piironen et al., 2002). A phytosterol-enriched constituent in PSB may enhance the production of activated sterolloaded elicitin, which induces severe necrotic development in Dendrobium cv. 'Earsakul' PLBs. These hypotheses are supported by our results, which revealed that MSB (synthetic media without natural ingredients) promoted mycelial growth, but induced the lowest severity of necrosis (Tables 2 and 3). Interestingly, this medium also induced the lowest quantity of $\alpha$-elicitin (Fig. 1).

\section{Conclusions}

We are the first to report a new $\alpha$-elicitin in CF of $P$. palmivora, the causal agent of Dendrobium black rot, which significantly matches $\alpha$-elicitin hibernalin from $P$. hibernalis and syringicin from $P$. syringae, sharing a high homology to several elicitins from diverse Phytophthora spp. infecting different host plants. Our results suggest that PSB is the most suitable medium for the promotion of $P$. palmivora growth, for the production of $\alpha$-elicitin and for inducing necrosis in Dendrobium cv. 'Earsakul' PLBs, therefore it can be used to produce CF efficient for screening of black rot resistance. The concentrations of $P$. palmivora $\mathrm{CF}$ and culture periods also affected PLB necrosis, and the most optimized condition for effective selection of resistant Dendrobium PLBs was $50 \%$ of CF selected after $21 \mathrm{~d}$. These results are crucial for the future development of black rot resistant Dendrobium.

\section{Acknowledgements}

The authors would like to thank Dr. Saengduen Moonsom, Dr. Watcharin Yuttavanichakul, Kanravee Issarangkul Na Ayuthaya, Supaporn baiya and Sukunya Chaipayang for their technical help and guidance with LCMS/MS analysis. We are very grateful to Peter Charles Bint for editing this manuscript. This work was supported by the Office of the Higher Education Commission under the NRU project of Thailand and grants from the Thailand Research Fund and Suranaree University of Technology, Thailand. 


\section{References}

Amusa NA (2006). Microbially produced phytotoxins and plant disease management. African Journal of Biotechnology 5:405-414.

Awuah RT, Frimpong M (2002). Cocoa-based media for culturing Phytophthora palmivora (Butl.) Butl., causal agent of black pod disease of cocoa. Mycopathologia 155:143-147.

Baillieul F, de Ruffray P, Kauffmann S (2003). Molecular cloning and biological activity of $\alpha, \beta$, and $\gamma$-megaspermin, three elicitins secreted by Phytophthoramegasperma H20. Plant Physiology 131:155-166.

Beever RE, Bollard EG (1970). The nature of the stimulation of fungal growth by potato extract. Journal of General Microbiology 60:273-279.

Behnke M (1979). Selection of potato callus for resistance to culture filtrates of Phytophthora infestansand regeneration of resistant plants. Theoretical and Applied Genetic 55:69-71.

Capasso R, Cristinziob G, Di Maroc A, Ferrantid P, Parentee A (2001). Syringicin, a new alpha-elicitin from an isolate of Phytophthora syringae, pathogenic to citrus fruit. Phytochemistry 58:257-262.

Capasso R, Di Maro A, Cristinzio G, De Martino A, Chambery A, Daniele A,... Parente A (2008). Isolation, characterization and structure-elicitor activity relationships of hibernalin and its two oxidized forms from Phytophthora bibernalis Carne 1925. Journal of Biochemistry 143:131-141.

Cating RA, Palmateer AJ, Stiles CM, Rayside PA (2010). Black rot of orchids caused by Phytopthora cactorum and Phytophthora palmivora in Florida. Plant Health Progress doi: 10.1094/PHP-2010-0614-01-DG.

Chee C-H, Newhook FJ (1965a). Improved methods for use in studies on Phytophthora cinnamomi Rands and other Phytophthora species. New Zealand Journal of Agricultural Research 8:88-95.

Chee C-H, Newhook FJ (1965b). Nutritional studies with Phytophthora cinnamomi Rands. New Zealand Journal of Agricultural Research 8:523-529.

Churngchow N, Rattarasarn M (2000). The elicitin secreted by Phytophthora palmivora, a rubber tree pathogen. Phytochemistry 54:3338.

Dahlin P, Srivastava V, Ekengren S, McKee LS, Bulone V (2017). Comparative analysis of sterol acquisition in the oomycetes Saprolegnia parasitica and Phytophthora infestans. PLoSOne 12(2), e0170873.

Dehgahi R, Zakaria L, Joniyas A, Subramaniam S (2014). Fusarium proliferatum culture filtrate sensitivity of Dendrobium sonia-28's PLBs derived regenerated plantlets. Malaysian Journal of Microbiology 10:241-248.

Derakhshan-Honaroarvar M,Hamedi MM, Pirouzifard MKh (2010). Rice bran phytosterols of three widespread Iranian cultivars. Journal of Agricultural Science and Technology 12:167-172.

Derevnina L, Dagdas FY, De la Concepcion JC, Bialas A, Kellner R, PetreB, ... Kamoun S (2016). Nine things to know about elicitins. New Phytologist 212:888-895.

Dokladal L, Oboril M, Stejkkal K, Zdrahal Z, Ptackova N, Chaloupkova R, ... Lochman J (2012). Physiological and proteomic approaches to evaluate the role of sterol binding in elicitin-induced resistance. Journal of Experimental Botany 63:2203-2215.
Dong S, Kong G, Qutob D, Yu X, TangJ, KangJ, ... Wang Y (2012). The NLP toxin family in Phytophthora sojae includes rapidly evolving groups that lack necrosis-inducing activity. Molecular Plant-Microbe Interactions 25:896-909.

Du J, Verzaux E, Chaparro-Garcia A, Bijsterbosch G, Keizer LCP, Zhou J, ... Vleeshouwers VG(2015).Elicitin recognition confers enhanced resistance to Phytophthora infestans in potato. Nature Plants 1:15034.

Elliott CG (1994). Reproduction in fungi: genetical and physiological aspects. Chapman and Hall,London.

Erwin DC, Ribeiro OK (1996). Phytophthora disease worldwide. American Phytopathological Society, Minnesota.

Esmaiel NM, Al-Doss AA, Barakat MN (2012). In vitro selection for resistance to Fusarium oxysporum $\mathrm{f}$. sp. dianthi and detection of genetic polymorphism via RAPD analysis in carnation. Journal of Medicinal Plants Research 6:3997-4004.

Fernanda AP, Cristiana CB, Sílvia LRM, Jaqueline GB, Eliana BF (2013). Activity of rice bran protein extracts against Fusarium graminearum. African Journal of Agricultural Research 8:6283-6290.

Gangopadhyay N, Hossain MB, Rai DK, Brunton NP (2015). A review of extraction and analysis of bioactives in oat and barley and scope for use of novel food processing technologies. Molecules 20:1088410909.

Hendrix JW (1964). Sterol induction of reproduction and stimulation of growth of Pythium and Phytophthora. Science 144:1028-1029.

Ho HH (1970). A study of growth and sporulation of Phytophthora megasperma var.sojae. Sydowia 24:51-58.

Jadon KS, Shah R, Gour HN, Sharma P (2015). Effect of environmental factors on toxin production of Drechslera bicolor, a causal agent of leat blight in bell pepper. African Journal of Microbiology Research 9:521526.

Jiang RHY, Tyler BM, Whisson SC, Hardham AR, Govers F (2006). Ancient origin of elicitin gene clusters in Phytophthoragenomes. Molecular Biology and Evolution 23:338-351.

Kamoun S, Young M, Glascock C, Tyler BM(1993). Extracellular protein elicitors from Phytophthora: host-specificity and induction of resistance to fungal and bacterial phytopathogens. Molecular Plant-Microbe Interactions 6:15-25.

Khairum A, Tharapreuksapong A, Wongkaew S, Tantasawat PA (2016). Cultural characteristics and pathogenicity analysis of Phytophthora palmivora, causal pathogen of black rot in orchids. In: Rahman MA, Dasic P (Eds). Proceedings of the International Conference on Agricultural, Food, Biological and Health Sciences (AFBHS-16). Kuala Lumpur, Malaysiapp 101-106.

Laemmli UK (1970). Cleavage of structural proteins during the assembly of the head of bacteriophage T4. Nature 227:680-685.

Lagarda ML, García-Llatas G, Farré R (2006). Analysis of phytosterols in foods. Journal of Pharmaceutical and Biomedical Analysis 41:14861496.

Lecomte M, Hamama L, Voisine L, Gatto J, Hélesbeux J-J, Séraphin D, ... Berruyer R (2014). Partial resistance of carrot to Alternaria dauci correlates with in vitro cultured carrot cell resistance to fungal exudates. PLoSOne 9(7), el01008. 
638

Levesque R, SPSS Inc. (2006). SPSS programming and data management. SPSS Institute (3rded), New York.

McMillan RT, Jr, Palmateer A, Cating RA (2009). Problems in controlling Phytopthora cactorum on Cattleya orchids. Proceedings of the Florida State Horticultural Society 122:426-428.

Moreau RA, Whitaker BD, Hicks KB (2002). Phytosterols, phytostanols, and their conjugates in foods: structural diversity, quantitative analysis, and health-promoting uses. Progress in Lipid Research 41:457-500.

Murashige T, Skoog F (1962). A revised medium for rapid growth and bioassays with tobacco tissue cultures. Physiologia Plantarum 15:473496.

Orlikowski LB, Szkuta G (2006). Phytophthora rot of some orchids - new disease in Poland. Phytopathologia Polonica 40:57-61.

Osman H,Vauthrin S, Mikes V, Milat M-L, Panabières F, Marais A, ... Blein J-P (2001). Mediation of elicitin activity on tobacco is assumed by elicitin-sterol complexes. Molecular Biology of the Cell 12:2825-2834.

Özdestan Ö, Erol T, Acar A (2014). Phytosterols in rice bran and usage of rice bran in food industry. In: Straumite E (Ed). Proceedings of 9th Baltic Conference on Food Science and Technology "Food for Consumer Well-Being" FoodBalt 2014, Jelgavapp 2427.

Oßwald W, Fleischmann F, Rigling D, Coelho AC, Cravador A, Diez J, ... Werres S (2014). Strategies of attack and defence in woody plant Phytophthora interactions. Forest Pathology 44:169-190.

Phungamngoen A, Sungsri-in M (2011). Antifungal activity of rice bran extracts against Colletotrichum gloeosporioides isolated from fresh and fresh-cut mango. Agricultural Science Journal 42:323-325.

Piironen V, Toivo J, Lampi A-M (2002). Plant sterols in cereals and cereal products. Cereal Chemistry 79:148-154.

Piironen V, Toivo J, Puupponen-Pimiä R, Lampi A-M (2003). Plant sterols in vegetables, fruits and berries. Journal of the Science of Food and Agriculture 83:330-337.

Ponchet M, Panabières F, Milat M-L, Mikes V, Montillet J-L, Suty L, ... Blein J-P (1999). Are elicitins cryptograms in plant-oomycete communications?. Cellular and Molecular LifeSciences 56:1020-1047.

Qi F, Gong Z-H, Huang W (2006). Study on the selection of cell mutant lines resistant to Phytophthora capsici in pepper. Journal of Northwest Sci-Tech University of Agriculture andForestry (Natural Science Edition) 34:83-88.

Rao S, Ramgoapl S (2010). Effect of Alternaria belianthi culture filtrate on callus and regeneration of plantlets from tolerant callus in sunflower (Helianthus annuus L.). Indian Journal of Biotechnology 9:187-191.

Rockefeller University (2016). Protocol for silver staining. Proteomics Resource Center. Retrieved 2016 Jan 10 from http://www.proteomics. rockefeller.edu/ms_silverStaining.

Rodpai R, Intapan PM, Thanchomnang T, Sanpool O, Janwan P, Laummaunwai P, ... Maleewong W (2016). Strongyloides stercoralis diagnostic polypeptides for human strongyloidiasis and their proteomic analysis. Parasitology Research 115:4007-4012.
Ryan E, Galvin K, O'Connor TP, Maguire AR, O’Brien NM (2007). Phytosterol, squalene, tocopherol content and fatty acid profile of selected seeds, grains, and legumes. Plant Foods for Human Nutrition 62:85-91.

Saubeau G, GaillardF, Legentil L, Nugier-Chauvin C, Ferrières V, Andrivon D, Val F (2014). Identification of three elicitins and a galactan-based complex polysaccharide from a concentrated culture filtrate of Phytophthora infestans efficient against Pectobacterium atrosepticum. Molecules 19:15374-15390.

Savita, Virk GS, Nagpal A (2011). In vitro selection of calli of Citrus jambhiri Lush. for tolerance to culture filtrate of Phytophthora parasitica and their regeneration. Physiology and Molecular Biology of Plants 17:41-47.

Sharma A, Wongkham C, Prasongwattana V, Boonnate P, Thanan R, Reungui S, Cha'on U (2014). Proteomic analysis of kidney in rats chronically exposed to monosodium glutamate. PLoS One 9(12), e116233.

Sopee J, Sangchote S, Stevenson WR (2012). Modified agar-based media for culturing Phytophthorainfestans. Phytoparasitica 40:269-278.

Souza MM, Oliveira MS, Rocha M, Furlong EB (2010). Antifungal activity evaluation in phenolic extracts from onion, rice bran, and Chlorella phyrenoidosa. Ciência e Tecnologia de Alimentos [Food Science and Technology] (Campinas) 30:680-685.

Stong RA, Kolodny E, Kelsey RG, González-Hernández MP, Vivanco JM, Manter DK (2013). Effect of plant sterols and tannins on Phytophthora ramorum growth and sporulation. Journal of Chemical Ecology 39:733743.

SumbaliG (2010). The fungi. AlphaScience International Ltd,, Oxford.

Uhlikková H, Obořil M, Klempová J, Šedo O, Zdráhal Z, Kašparovský T, ... Lochman J (2016). Elicitin-induced distal systemic resistance in plants is mediated through the protein-protein interactions influenced by selected lysine residues. Frontiers in Plant Science 7:59.

Valencia LDC, Pascual CB, Delfin EF (2014). In-vitro selection of pineapple cv. 'Queen' with resistance to culture filtrate of Phytophthora cinnamomi Rands. Philippine Journal of Crop Science 39:58-66.

Widmer TL (2014). Phytophthora palmivora. Forest Phytophthoras. Retrieved 2017 August 12 from http://dx.doi.org/10.5399/ osu/fp.4.1.3557.

Yoder OC (1980). Toxins in pathogenesis. Annual Review of Phytopathology 18:103-129.

Zipfel C, Robatzek S (2010). Pathogen-associated molecular patterntriggered immunity: veni, vidi...?. Plant Physiology 154:551-554. 